Vojislava V. Milutinović ${ }^{1}$ Vladimir M. Milutinović

${ }^{1}$ Gradski zavod za hitnu medicinsku pomoć Beograd, Srbija

${ }^{2}$ Opšta bolnica Valjevo, Srbija

\section{Dva lica plućne embolije}

\section{Sažetak}

Cilj rada. Prikazati dva u potpunosti različita slučaja kliničke manifestacije plućne embolije sa kojima se autor susreo u terenskim uslovima. Kod oba pacijenta $S T$ angiografijom utvrđena je masivna embolija pluća.

Metodologija. Korišćeni su podaci iz medicinske dokumentacije dva pacijenta.

Prikaz slučaja. Prvi slučaj; muškarac star 62 godine, koji je pozvao Službu hitne medicinske pomoći zbog iznenadno nastalog intenzivnog bola $u$ grudima u vidu pritiska, praćenog preznojavanjem i trnjenjem u obe šake. Tahipnoičan, $\mathrm{SaO} 280 \%$, nad plućima se auskultatorno čuje oslabljen disajni šum levo bazalno, TA 110/60 $\mathrm{mmHg}$ obostrano. Elektrokardiogram registruje sinusni ritam, srčane frekvencije 90/min., novonastali inkompletni blok desne grane, aplatiran $T$ talas u prekordijalnim odvodima. Onkološki pacijent, sa gipsanom imobilizacijom zbog preloma desne potkolenice, pre 9 godina imao emboliju pluća. Pacijent je transportovan u dežurnu ustanovu, sa uputnom dijagnozom embolije pluća, koja je i dokazana CT pregledom plućne arterije.

Drugi je slučaj mlađeg muškarca starog 48 godina, koji je imao kratkotrajni gubitak svesti sa spontanim vraćanjem u svesno stanje, zbog čega ukućani zovu službu hitne medicinske pomoći. Prethodno zdrav, bivši aktivni sportista, bez faktora rizika za kardiovaskularne bolesti, kao i bez predisponirajućih faktora za nastanak tromboze dubokih vena. Po dolasku ekipe, žali se samo na malaksalost. Eupnoičan, auskultatorno nad plućima se čuo normalan disajni šum, SaO2 98\%, TA 120/80 mmHg obostrano. Elektrokardiogram (EKG) registruje sinusni ritam, srčane frekvencije 110/ min., $Q S$ u $\mathrm{V}_{1}-\mathrm{V}_{3}, S T$ elevacija $1 m m \mathrm{u} \mathrm{V}_{2}-\mathrm{V}_{3}$. Transportovan kardiologu, $h s$ troponin $T$ 194, primljen u koronarnu jedinicu pod dijagnozom akutnog infarkta miokarda. Naknadna $C T$ angiografija registruje masivnu plućnu emboliju.

Diskusija i zaključak. Za tačno postavljanje dijagnoze plućne embolije najvažnije je da se posumnja na ovo oboljenje. Problem je što klinički znaci i simptomi nisu specifični, te se PE često ne dijagnostikuje na vreme ili, u nekim slučajevima, ostane i neprepoznata. U terenskim uslovima su nam dijagnostičke mogućnosti ograničene, što otežava postavljanje dijagnoze. U svim slučajevima neobjašnjive sinkope i tahikardije razmotriti mogućnost postojanja PE. O plućnoj emboliji treba misliti i kada nedostaju faktori rizika.

Ključne reči: plućna embolija, bol u grudima, sinkopa, $C T$ angiografija 


\section{Uvod}

Plućna embolija (PE) je patološko stanje nastalo usled opstrukcije manjih ili većih grana plućne arterije trombom ili drugim materijalima, koji putem venske krvi, kroz desno srce, dospevaju u plućnu cirkulaciju [1]. To je treća najčešća kardiovaskularna bolest posle ishemijske bolesti srca i cerebrovaskularnog insulta, sa ukupnom godišnjom incidencijom od 100-200/100.000 stanovnika [2]. U $95 \%$ slučajeva uzrok ovog oboljenja je tromboembolus, najčešće poreklom iz dubokih vena donjih ekstremiteta. Uglavnom se javlja tri do sedam dana od nastanka tromboze dubokih vena, a u $10 \%$ slučajeva je fatalna, najčešće u prvom satu od pojave simptoma.

U zavisnosti od rizika intrahospitalnog ili 30dnevnog mortaliteta i kliničkih manifestacija, plućna embolija se klasifikuje kao visokorizična i niskorizična. Pod visokorizičnom PE se podrazumeva suspektna ili potvrđena PE u prisustvu šoka ili perzistentne hipotenzije (sistolni krvni pritisak $<90 \mathrm{mmHg}$ ili pad sistolnog krvnog pritiska za najmanje $40 \mathrm{mmHg}$ pod uslovom da nisu uzrokovani novonastalom aritmijom, hipovolemijom i sepsom). Niskorizična plućna embolija podrazumeva odsustvo šoka ili perzistentne hipotenzije [1].

Snažni faktori rizika za nastanak tromboze dubokih vena, a samim tim i embolije pluća jesu: velika trauma, hirurške intervencije koje zahtevaju opštu anesteziju dužu od 30 minuta, prelomi donjih ekstremiteta, zamena veštačkog kuka i povreda kičmene moždine. Umereni faktori rizika su: malignitet, oralna kontracepcija, in vitro fertilizacija, trombofilije, transfuzija krvi, prethodni venski tromboembolizam, starost preko 70 godina, gojaznost, laparoskopska hirurgija i ostali[3]. Poznavanje faktora rizika je važno u određivanju verovatnoće PE, što se povećava sa brojem prisutnih faktora, međutim, kod čak $40 \%$ bolesnika sa plućnom embolijom ne mogu se otkriti faktori koji je izazivaju $[4,5,6,7]$.

Klinička slika nije specifična. U najvećem broju slučajeva prisutna je iznenada nastala dispneja u miru $(50 \%)$, bol u grudima pleuritičkog karaktera (40\%), dispneja pri naporu (27\%), kašalj $(23 \%)$, bol u grudima ishemijskog tipa (15\%), jednostrani otok ekstremiteta (24\%). Sinkopa se javlja u svega 5\% slučajeva $[8,9]$, a čak $40 \%$ pacijenata sa plućnom embolijom ima normalnu saturaciju kiseonikom arterijske krvi.

U elektrokardiogramu mogu biti prisutni pokazatelji opterećenja desne komore, kao što su skretanje srčane osovine udesno, novonastali $S_{1} Q_{3} T_{3}$, novonastali inkompletni ili kompletni blok desne grane, negativni $T$ talasi ili depresija $S T$ segmenta u odvodima $\mathrm{V}_{1}-\mathrm{V}_{4}$, kao znaci ishemije desne komore. Ove EKG promene se obično nalaze $u$ težim slučajevima PE, u blažim slučajevima može se naći samo sinusna tahikardija prisutna kod $40 \%$ pacijenata [2].

Budući da klinička slika nije specifična, za kliničku procenu verovatnoće postojanja PE mogu se koristiti različiti skorovi, od kojih se najčešće upotrebljava Velsov (Wells) skor.

\section{Cilj rada}

Cilj rada je da prikaže dva u potpunosti različita slučaja kliničke manifestacije plućne embolije sa kojima se autor susreo u terenskim uslovima. Kod oba pacijenta $C T$ angiografijom utvrđena je masivna plućna embolija.

\section{Materijal i metod}

Korišćeni su podaci iz medicinske dokumentacije za prikaz slučajeva dva pacijenta sa plućnom tromboembolijom.

\section{Prikaz slučaja}

Prvi slučaj je prikaz muškarca starog 62 godine, koji je pozvao Službu hitne medicinske pomoći zbog iznenadno nastalog intenzivnog bola $\mathrm{u}$ grudima $u$ vidu pritiska praćenog bledilom, preznojavanjem i trnjenjem $u$ obe šake; bol se širi preko celog prekordijuma i traje sat vremena. Tahipnoičan, $\mathrm{SaO}_{2} \quad 80 \%$, nad plućima oslabljen disajni šum levo bazalno, TA 110/60 $\mathrm{mmHg}$ obostrano. Leči se od multiplog mijeloma, ima gipsanu imobilizaciju desne potkolenice zbog preloma od pre mesec dana, pre 9 godina imao emboliju pluća. Elektrokardiogram (EKG) registruje sinusni ritam, srčane frekvencije 90/min., novonastali inkompletni blok desne grane, aplatiran $T$ talas u prekordijalnim odvodima (Slika 1).

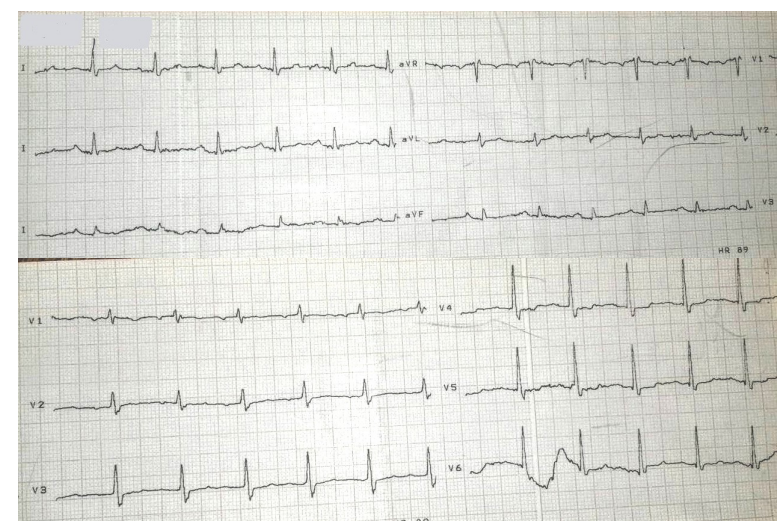

Slika 1. EKG prvog pacijenta pokazuje novonastali inkompletni blok desne grane i aplatiran $T$ talas u prekordijalnim odvodima. Figure 1. The ECG of the first patient shows the newcomer and the incomplete block of the right branch and the assigned $\mathrm{T}$ wave in precordial leads. 
Pacijent je transportovan $\mathrm{u}$ dežurnu ustanovu, sa uputnom dijagnozom embolije pluća. Laboratorijske analize pri prijemu: D-dimer 31.96, NTproBNP 1024 , hs troponin $T$ 415, $C K$ 56, gasne analize arterijske krvi - $p \mathrm{H}$ 7.46, $\mathrm{pO}_{2} 6.6 \mathrm{kPa}, \mathrm{pCO}_{2} 3.85 \mathrm{kPa}$. Ehokardiografski nalaz: "Aorta je šira u korenu i ascendentnom delu (do 4,4 cm), dobre sistolne separacije veluma, sa malom $A R 1^{+}$centralnog mlaza. Leva komora je normalnih dimenzija $(5.4 / 3.5 \mathrm{~cm})$, normalne debljine zidova, usporene relaksacije, očuvane ukupne kontraktilnosti, EF oko $60 \%$. Septum celom dužinom prožet crtastim i sitnozrnastim fibrozama i nešto je rigidniji u odnosu na suprotan zid. Mitralna valvula je blago sklerotično izmenjena, dobre pokretljivosti, $L P K$ je normalne veličine. Desna komora je normalne veličine $(2.7$ $\mathrm{cm}$ ), normalne kinetike (TAPSE $19 \mathrm{~mm}$ ), TR 1-2, SPDK $29 \mathrm{mmHg}$. Perikard prazan, $C T$ pregledom plućne arterije registrovane su masivne trombotične mase u obe a. pulmonalis, kao i lobarnim granama za gornji i donji režanj obostrano, te segmentnim granama (Slika 2).

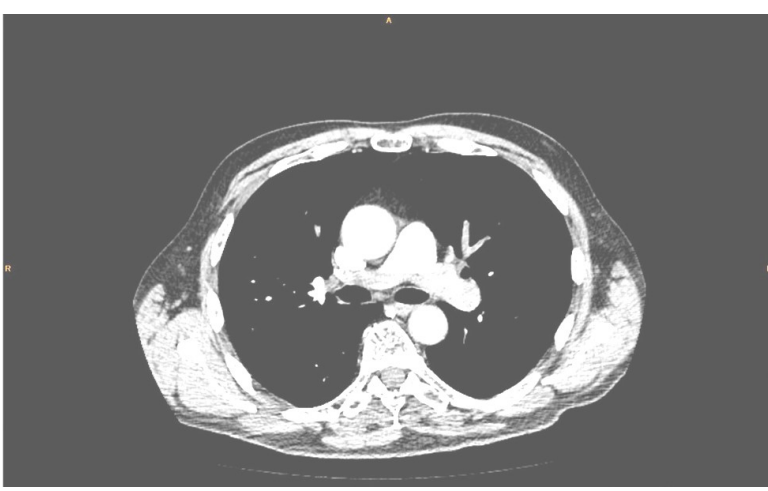

Slika 2. MDCT angiografija plućne arterije, na kojoj se uočava masivna tromboza glavnih grana plućne arterije.

Figure 2. MDCT angiography of the pulmonary artery shows a masive thrombosis of the main branches of the pulmonary artery.

Drugi slučaj je prikaz muškarca starog 48 godina, koji je u kasnim večernjim satima nakon defekacije imao kratkotrajni gubitak svesti sa spontanim rasvešćivanjem, zbog čega ukućani zovu Službu hitne medicinske pomoći. Prethodno zdrav, bivši aktivni sportista, bez faktora rizika za kardiovaskularne bolesti, kao i bez predisponirajućih faktora za nastanak tromboze dubokih vena. Po našem dolasku, žalio se samo na malaksalost. Eupnoičan, nad plućima normalan disajni šum, $\mathrm{SaO}_{2}$ 98\%, TA 120/80 mmHg obostrano. EKG registruje sinusnu tahikardiju 110/min., $Q S$ u $V_{1}-V_{3}, \quad S T$ elevacija $1 \mathrm{~mm}$ u $V_{2}-V_{3}$ (Slika 3).
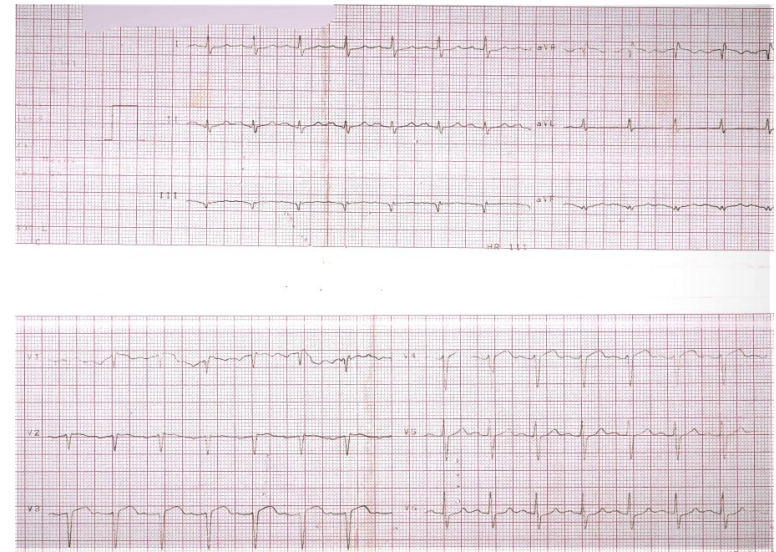

Slika 3. EKG drugog pacijenta pokazuje sinusnu tahikardiju, $Q S$ u $V_{1}-V_{3}$ i $S T$ elevaciju $1 \mathrm{~mm}$ u $V_{2}$ i $V_{3}$.

Figure 3. The ECG shows sinus tachycardia, $Q S$ in $\mathrm{V}_{1}-V_{3}$ and $S T$ elevation $1 \mathrm{~mm}$ in $V_{2}$ and $V_{3}$.

Transportovan je kardiologu, hs troponin $T$ 194, primljen $\mathrm{u}$ koronarnu jedinicu pod dijagnozom akutnog infarkta miokarda. Naknadna $C T$ angiografija registruje masivne trombotične mase obostrano u glavnim, lobarnim i segmentnim granama plućne arterije (Slika 4).

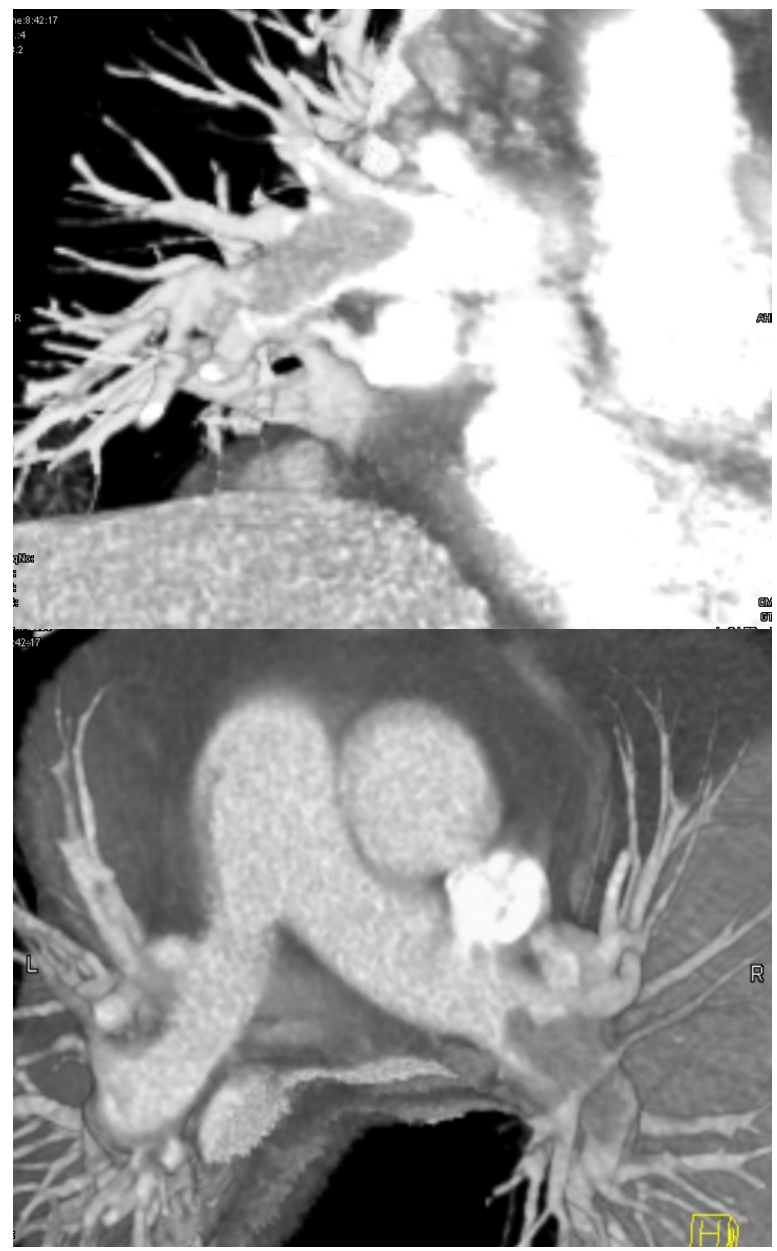

Slika 4. MDCT angiografija plućne arterije na kojoj se uočava masivna tromboza desne grane plućne arterije.

Figure 4. MDCT angiography of the pulmonary artery shows a massive thrombosis of the right branch of the pulmonary artery. 


\section{Diskusija i zaključak}

Za tačno postavljanje dijagnoze embolije pluća najvažnije je da se posumnja na ovo oboljenje. Problem je što klinički znaci i simptomi nisu specifični, te se PE često ne dijagnostikuje na vreme ili, u nekim slučajevima, ostane i neprepoznata. Problem koji se javlja kod dijagnostikovanja plućne embolije jeste preterano i prečesto postavljanje dijagnoze, pa je tako utvrđeno da se kod manje od $35 \%$ pacijenata za koje se sumnja da imaju plućnu emboliju ona zaista i potvrdi [9].

U terenskim uslovima dijagnostičke mogućnosti su ograničene, što otežava postavljanje dijagnoze.

Prvi pacijent je imao više faktora rizika za PE, jasnu kliničku sliku, visoku kliničku verovatnoću (Wells skor 7), $\mathrm{SaO}_{2} 80 \%$ i EKG koji je olakšao postavljanje dijagnoze. Drugi pacijent nije imao poznate faktore rizika za PE, nejasnu kliničku sliku, nisku kliničku verovatnoću (Wells skor 1,5), $\mathrm{SaO}_{2}$ 98\% i EKG koji je otežao postavljanje dijagnoze. Kod oba pacijenta utvrđena je masivna plućna embolija.

U svim slučajevima neobjašnjive sinkope i tahikardije uvek treba razmotriti mogućnost postojanja PE. O plućnoj emboliji treba misliti i kada nedostaju faktori rizika. 


\section{Literatura:}

1. Ivošević T, Kalezić N, Bradić Ž i sar. Plućna embolija. U: Kalezić N. urednik. Inicijalni tretman urgentnih stanja u medicini. Drugo izmenjeno i dopunjeno izdanje. Beograd, Medicinski fakultet, 2016; str. 541-558.

2. Konstantinides S, Torbicki A, Agnelli G et al. 2014 ESC Guidelines on the diagnosis and management of acute pulmonary embolism. Eur Heart J 2014;35:3033-3073.

3. Anderson FAJr., Spencer FA. Risk factors for venous

thromboembolism. Circulation, 2003; vol. 107 (23 Suppl.):19-116.

4. White RH. The epidemiology of venous thromboembolism. Circulation, 2003, vol. 107 (23 Suppl 1):14-18. 5. Cushman M, Tsai A, Heckbert SR et al. Incidence rates, case fatality and recurrence rates of deep venous thrombosis and pulmonary embolus: the Longitudinal Investigation of Thromboembolism Etiology (LITE). Thromb Haemost 2001;86 (Suppl 1):OC 2349.

6. Jimenez S, Ruiz-Artacho P, Merlo M et al. Risk profile, management, and outcomes of patients with venous thromboembolism attended in Spanish Emergency Departments. The ESPHERIA registry. Medicine (Baltimore). 2017;96(48):e8796.

7. Heit JA, O'Fallon WM, Petterson TM et al. Relative impact of risk factors for deep vein thrombosis and pulmonary embolism: a population-based study. Arch Intern Med. 2002;162:1245-1248.

8. Pollack CV, Schreiber D, Goldhaber SZ et al. Clinical characteristics, management and outcomes of patients diagnosed with acute pulmonary embolism in the emergency department: initial report of EMPEROR (Multicenter Emergency Medicine Pulmonary Embolism in the Real World Registry). J Am Coll Cardiol, 2011; vol. 57(6): 700-706.

9. Miniati M, Prediletto R, Formichi B et al. Accuracy of clinical assessment in the diagnosis of pulmonary embolism. Am J Respir Crit Care Med, 1999; vol. 159 (3): 864-871. 


\title{
Two faces of pulmonary embolism
}

\begin{abstract}
Objective. The aim of this paper is to present two completely different clinical manifestations of pulmonary embolism which the author encountered in the field. In both cases CT angiography confirmed massive embolism.

Vojislava V. Milutinović1,

Vladimir M. Milutinović

${ }^{1}$ City Institute for Emergency Medicine Belgrade, Serbia

${ }^{2}$ General Hospital Valjevo, Serbia

Methodology. The data from medical documentation were used to present cases of two patients with pulmonary embolism.

Case report. The first one presents a case of a 62-year-old man who called emergency service because of a sudden intense pressure-like chest pain, accompanied by sweating and tingling in both hands. Physical exam showed tachypnea, $\mathrm{SaO} 2$ of $80 \%$, with auscultatory finding of weakened breath sound on left side basal, $\mathrm{BP}=110 / 60 \mathrm{mmHg}$ on both sides. ECG registered sinus rhythm, HR $=90 / \mathrm{min}$, new incomplete right bundle branch block and flattened $\mathrm{T}$ wave in precordial leads. Patient's history revealed an oncologic diagnosis, plaster immobilization on right lower leg and previous pulmonary embolism 9 years ago. The patient was transported to the emergency medical institution, with suspected diagnosis of pulmonary embolism, which was eventually confirmed by CT pulmonary angiography.

The other is the case of a 48-year-old man presenting with short-term loss of consciousness followed by spontaneous recovery, which was the reason for contacting the emergency service. Healthy, former active athlete, without any risk factors for cardiovascular disease, also without predisposing factors for the development of deep vein thrombosis. Upon our arrival, he complained only of languor. Physical exam showed eupnea, with normal breath sounds, $\mathrm{SaO} 2$ 98\%, $\mathrm{BP}=120 / 80 \mathrm{mmHg}$ on both sides. The ECG registered sinus rhythm, HR= $110 / \mathrm{min}$, QS in V1-V3, ST elevation $1 \mathrm{~mm}$ in V2-V3. The patient was transported to the cardiology department. Because of the hs troponin $\mathrm{T}=194$, he was admitted to the cardiology ICU with a working diagnosis of acute myocardial infarction. Subsequent CT angiography registered a massive pulmonary embolism.
\end{abstract}

Discussion and conclusion. In order to make the correct diagnosis of pulmonary embolism, it is necessary to keep high level of suspicion. The fact that clinical signs and symptoms are not specific is the reason why PE often isn't diagnosed in time or remains unrecognized in some cases. In field conditions, with limited diagnostic possibilities, establishing the diagnosis of PE is particularly challenging.

In all cases of unexplained syncope and tachycardia, the possibility of PE should be considered. We need to think about pulmonary embolism even when risk factors are absent.

Key words: pulmonary embolism, chest pain, syncope, CT angiography 